\title{
PENERAPAN CABRI II PLUS UNTUK MENINGKATKAN KEMAMPUAN PEMAHAMAN MATEMATIS DAN MOTIVASI BELAJAR SISWA DALAM PEMBELAJARAN MATEMATIKA
}

\author{
Rezkiyana Hikmah ${ }^{1}$, Purni Munah Hartuti ${ }^{2}$ \\ Program Studi Informatika, Universitas Indraprasta PGRI ${ }^{1,2}$ \\ Email: rezkiyana.hikmah2706@gmail.com
}

\begin{abstract}
Abstrak
Penelitian ini bertujuan menelaah peningkatan kemampuan pemahaman matematis siswa yang belajar dengan cabri II plus dan siswa yang belajar dengan pembelajaran biasa serta menelaah motivasi belajar siswa yang belajar dengan cabri II plus. Penelitian ini termasuk kuasi eksperimen dengan desain kelompok kontrol non ekuivalen dengan teknik purposive sampling. Populasi penelitian adalah siswa kelas VII SMP Cibinong dengan jumlah siswa kelas eksperimen dan kontrol adalah 30 siswa. Instrumen yang digunakan adalah pretes dan postes kemampuan pemahaman matematis siswa serta lembar angket motivasi belajar untuk siswa kelas eksperimen. Data dianalisis dengan uji perbedaan dua rataan Mann-Whitney dan uji t. Hasil penelitian menunjukkan bahwa peningkatan kemampuan pemahaman matematis siswa yang belajar dengan cabry II plus tidak lebih baik daripada siswa yang belajar dengan pembelajaran biasa. Motivasi belajar siswa dengan software cabry II plus secara keseluruhan termasuk dalam kategori motivasi sedang.
\end{abstract}

Kata Kunci: software cabry II plus

Abstract

This research aims to study the improvement of mathematical understanding ability of students studying with cabri II plus and students studying with traditional learning and to examine the learning motivation of students studying with cabri II plus. The research uses a quasi-experimental research design with non-equivalent control groups formed using purposive sampling technique. The research population is seventh grade students of Cibinong Junior High School with 30 students in the experimental and control classes. The instruments used are a pretest and posttest on students mathematical comprehension ability and a questionnaire on learning motivation for the experimental class students. Data are analyzed using Mann-Whitney $U$ test and t test. The results show that the increase in the of mathematical understanding ability of students studying with cabry II plus is no better than students studying with traditional learning. The learning motivation of students studying with Chili II plus software in general belongs to a medium motivation category. Keywords: cabry II plus software

\section{PENDAHULUAN}

Pentingnya peran teknologi dalam pendidikan dapat dilihat dengan banyaknya muncul aplikasi software pembelajaran. Para guru diharapkan mampu memberdayakan software pembelajaran tersebut dalam pembelajaran di kelas, seperti laptop, komputer, maupun aplikasi software pembelajaran. Guru diharapkan tidak hanya mampu menyajikan materi secara ekspositori atau kooperatif, akan tetapi guru juga diharapkan mampu menguasai teknologi informasi dalam pembelajaran di kelas. Hal ini merupakan salah satu cara untuk mendesain pembelajaran yang menarik, sehingga memunculkan pembelajaran yang variatif, menyenangkan dan efisien. Hal tersebut berguna untuk meningkatkan kualitas dalam pembelajaran. Penggunaan teknologi informasi ini dapat dimanfaatkan secara maksimal jika guru memiliki kemampuan dalam menggunakan teknologi informasi yang baik. Oleh karena itu, penting bagi guru untuk belajar teknologi informasi sehingga dapat menggunakan aplikasi software pembelajaran yang sesuai dengan perkembangan yang ada. 
Salah satu aplikasi software yang dapat dimanfaatkan dalam pembelajaran geometri bidang datar, adalah cabri II plus. aplikasi ini memiliki kegunaan untuk mengkonstruksi bangun datar, menghitung panjang segmen, keliling, luas dan besar sudut. Aplikasi ini dapat mengkonstruksi dan menggambar bangun sesuai dengan ukuran yang akurat dan teliti. Segmen dan sudut-sudut yang dibentuk juga sesuai dengan ukuran segmen maupun sudut yang hendak dikonstruksi sehingga dapat mengurangi galat dalam menggambar sebuah bangun datar. Penggunaan aplikasi ini dapat membantu siswa dalam memahami konsep bangun datar sehingga siswa juga dapat diajak untuk mengkonstruksi bangun datar sendiri dengan bantuan cabri II plus. Siswa dapat menafsirkan pemahamannya dalam bentuk ide-ide, gambar dan simbol. Penggunaaan aplikasi ini juga dapat meningkatkan motivasi belajar siswa dalam belajar geometri. Hal ini disebabkan pembelajaran didesain dengan berbantu teknologi informasi berupa aplikasi cabri II plus sehingga menumbuhkan rasa ketertarikan siswa dalam belajar geometri.

Tujuan dari penelitian adalah untuk menelaah peningkatan kemampuan pemahaman matematis siswa yang belajar dengan cabri II plus lebih baik daripada siswa yang belajar dengan pembelajaran biasa dan penggunaan cabri II plus dalam meningkatkan motivasi belajar siswa dalam geometri bidang datar. Berdasarkan tujuan tersebut, penelitian ini dapat memberikan manfaat yaitu kemampuan pemahaman matematis siswa dapat ditingkatkan dan guru dapat menggunakan software cabry II plus sebagai salah satu variasi guru dalam pembelajaran matematika.

Cabri II plus merupakan salah satu software yang dapat digunakan dalam pembelajaran geometri bidang datar. Cabri II plus dapat dikatakan salah satu media pembelajaran yang variatif. Hal ini disebabkan cabri II plus dioperasikan menggunakan bantuan teknologi informasi. Oleh karena itu, software ini dapat digunakan sebagai salah satu cara yang dapat dilakukan guru untuk menanamkan konsep geometri bangun datar.

Cabri II plus ini dapat membantu guru dalam mengkonstruksi segemen, sudut dan bangun datar sesuai dengan perhitungan yang akurat, sehingga dapat menghindarkan guru dari kesalahan dalam menggambar bangun sesuai ukuran yang teliti.

"Referensi [3] menyatakan bahwa ada empat hal yang dapat dicapai siswa dengan bantuan cabri II plus dalam pembelajaran geometri, yaitu; (1) siswa dapat membangun kemampuan pemecahan masalah dengan menggunakan software, (2) membangun skema mental melalui konstruksi dengan menggunakan skema, (3) meningkatkan kemampuan reaksi visual melalui kegiatan representasi visual, dan (4) membangun proses pemikiran mengenai geometri”.

"Referensi [2] menyatakan bahwa kemampuan pemahaman siswa dalam belajar merupakan hal penting untuk tercapainya tujuan dari pembelajaran matematika, artinya siswa yang memiliki pemahaman terhadap materi atau suatu konsep matematika akan terlihat dari bagaimana siswa tersebut menyelesaikan masalah yang berhubungan dengan matematika".

\section{METODE}

Penelitian ini bertujuan untuk menelaah peningkatan kemampuan pemahaman matematis siswa yang belajar dengan cabri II plus lebih baik daripada siswa yang 
belajar dengan pembelajaran biasa dan penggunaan cabri II plus dalam meningkatkan motivasi belajar siswa dalam geometri bidang datar. Penelitian ini termasuk penelitian eksperimen semu.

"Referensi [1] menunjukkan bahwa penelitian ini menggunakan desain kelompok kontrol non ekuivalen sebagai berikut.

Kelas eksperimen $\quad: \mathrm{O} \quad \mathrm{X} \quad \mathrm{O}$

Kelas kontrol $\quad \div \mathrm{O}---\mathrm{O}-$

Keterangan:

O : Pretest atau Postest

$\mathrm{X} \quad$ : Pembelajaran dengan cabri II plus

- - - : Subyek tidak diperoleh secara acak".

Populasi penelitian ini adalah siswa SMP PGRI 1 Cibinong pada semester 2 di Cibinong, Provinsi Jawa Barat Tahun Pelajaran 2017/2018. Materi yang digunakan adalah bangun datar. Sampel pada penelitian adalah siswa kelas VII SMP PGRI 1 Cibinong.

Penelitian ini menggunakan instrumen tes kemampuan pemahaman pada masingmasing kelas (eksperimen dan kontrol) berupa tes awal (pretest) dan tes akhir (postest) dengan soal yang sama. Pemberian soal yang sama ini dilakukan untuk melihat ada atau tidaknya peningkatan akibat perlakuan sehingga akan lebih baik jika diukur dengan soal yang sama.

Penelitian ini menggunakan teknik purposive sampling dalam pengambilan sampel. Penelitian ini menggunakan dua kelas yaitu kelas eksperimen (pembelajaran dengan cabri II plus) dan kelas kontrol (pembelajaran biasa).

\section{HASIL DAN PEMBAHASAN}

Prosedur yang dilakukan untuk menguji statistik yang digunakan adalah melakukan uji normalitas dengan uji Kolmogorov-
Smirnov dan uji homogenitas varians (uji Levene's).

Tabel 1. Hasil Uji Normalitas Skor Kemampuan Pemahaman Matematis

\begin{tabular}{|c|c|c|c|c|c|c|}
\hline \multirow{2}{*}{$\underset{\text { uan }}{\text { Kemamp }}$} & \multirow[t]{2}{*}{ Nilai } & \multirow{2}{*}{$\begin{array}{l}\text { Kel } \\
\text { as }\end{array}$} & \multicolumn{3}{|c|}{$\begin{array}{c}\text { Uji Kolmogorov } \\
\text {-Smirnov }\end{array}$} & \multirow[t]{2}{*}{ Ket } \\
\hline & & & Stat & df & Sig & \\
\hline \multirow{6}{*}{$\begin{array}{c}\text { Pemaham } \\
\text { an }\end{array}$} & \multirow{2}{*}{ Pretes } & Eks & $\begin{array}{c}0,15 \\
9\end{array}$ & 30 & $\begin{array}{c}0,05 \\
2\end{array}$ & $\begin{array}{c}\text { Terima } \\
H_{0}\end{array}$ \\
\hline & & K & $\begin{array}{c}0,15 \\
6\end{array}$ & 30 & 0,06 & $\begin{array}{c}\text { Terima } \\
H_{0}\end{array}$ \\
\hline & \multirow{2}{*}{ Postes } & Eks & $\begin{array}{c}0,93 \\
5\end{array}$ & 30 & $\begin{array}{c}0,06 \\
7\end{array}$ & $\begin{array}{c}\text { Terima } \\
H_{0}\end{array}$ \\
\hline & & $\mathrm{L}$ & $\begin{array}{c}0,93 \\
1\end{array}$ & 30 & $\begin{array}{c}0,05 \\
3\end{array}$ & $\begin{array}{c}\text { Terima } \\
H_{0}\end{array}$ \\
\hline & \multirow{2}{*}{$\begin{array}{l}\mathrm{N}- \\
\text { Gain }\end{array}$} & Eks & $\begin{array}{c}0,18 \\
6\end{array}$ & 30 & $\begin{array}{c}0,00 \\
9\end{array}$ & $\begin{array}{c}\text { Tolak } \\
H_{0}\end{array}$ \\
\hline & & K & $\begin{array}{c}0,12 \\
7\end{array}$ & 30 & 0,2 & $\begin{array}{c}\text { Terima } \\
H_{0}\end{array}$ \\
\hline
\end{tabular}

Berdasarkan uji normalitas, data pretes dan postes kemampuan pemahaman matematis berdistribusi normal. Uji homogenitas varians dilakukan dengan uji Levene's. Adapun hipotesis statistik yang diuji pada data pretes, postes dan N-Gain kemampuan pemahaman matematis adalah sebagai berikut.

$\mathrm{H}_{\mathrm{o}}$ : Kedua data pretes bervariansi homogen $\mathrm{H}_{\mathrm{a}}$ : Kedua data pretes tidak bervariansi homogen

Selanjutnya rumusan hipotesis yang diuji pada data postes kemampuan pemahaman matematis adalah sebagai berikut.

$\mathrm{H}_{\mathrm{o}}$ : Kedua data postes bervariansi homogen

$\mathrm{H}_{\mathrm{a}}$ : Kedua data postes tidak bervariansi homogeny

Tabel 2. Hasil Uji Homogenitas Varians

Kemampuan Pemahaman Matematis

\begin{tabular}{|c|c|c|c|c|c|c|}
\hline Ke & & Le & le's & est & & \\
\hline $\begin{array}{c}\text { ma } \\
\text { mpu } \\
\text { an }\end{array}$ & Nilai & $\begin{array}{c}\text { Levene' } \\
\text { s } \\
\text { Statistic }\end{array}$ & $\begin{array}{c}\text { df } \\
1\end{array}$ & $\begin{array}{c}\text { df } \\
2\end{array}$ & $\begin{array}{c}\text { Si } \\
\text { g }\end{array}$ & Ket \\
\hline \multirow{2}{*}{$\begin{array}{l}\text { Pem } \\
\text { aha } \\
\text { man }\end{array}$} & Pretes & 0,263 & 1 & 58 & $\begin{array}{l}0, \\
61\end{array}$ & Terima $H_{0}$ \\
\hline & Postes & 1,135 & 1 & 58 & $\begin{array}{c}0, \\
29\end{array}$ & Terima $H_{0}$ \\
\hline
\end{tabular}


Pada Tabel 2 dapat dilihat bahwa nilai Levene's Sig pretes dari hasil uji homogenitas varians adalah 0,61. Hal tersebut menunjukkan bahwa nilai Levene's Sig lebih tinggi dari nilai $\alpha=0,05$ sehingga varians skor pretes di kelas eksperimen dan kontrol adalah homogen. Hal yang sama juga untuk nilai nilai Levene's Sig postes lebih tinggi dari nilai $\alpha=0,05$ sehingga varians skor postes di kelas eksperimen dan kontrol adalah homogen. Oleh karena itu, dapat disimpulkan bahwa $\mathrm{H}_{\mathrm{o}}$ diterima.

\section{Tabel 3. Hasil Uji Kesamaan Dua Rerata} Pretes Kemampuan Pemahaman Matematis

\begin{tabular}{cccc}
\hline Kemampuan & Df & Sig & Ket \\
\hline Pemahaman & 58 & 0,223 & $\begin{array}{c}\text { Terima } \\
\mathrm{H}_{\mathrm{o}}\end{array}$ \\
\hline
\end{tabular}

Pada Tabel 3 dapat dilihat bahwa nilai sig pretes kemampuan pemahaman matematis lebih rendah dibanding dengan nilai $\alpha=$ 0,05 yang berarti $\mathrm{H}_{\mathrm{o}}$ diterima. Hal tersebut dapat diartikan bahwa kemampuan pemahaman matematis siswa dari kelas eksperimen dan kelas kontrol tidak perbedaan signifikan. Selanjutnya, untuk melihat adanya perbedaan atau tidak pada peningkatan kemampuan pemahaman matematis siswa maka digunakan data nilai postes atau n-gain. Hipotesis penelitian ini adalah peningkatan kemampuan pemahaman matematis siswa yang belajar dengan cabri II plus lebih baik daripada siswa yang belajar dengan pembelajaran biasa.

Tabel 4. Hasil Uji Perbedaan Dua Rerata Postes Kemampuan Pemahaman Matematis Siswa t-test for aquality of means

\begin{tabular}{cccccc}
\multicolumn{7}{c}{ t-test for aquality of means } \\
Skor & T & $\begin{array}{c}\text { Dig. } \\
\text { D } \\
\text { f }\end{array}$ & $\begin{array}{c}\text { Sig. 1- } \\
\text { taile } \\
\text { tailed }\end{array}$ & $\begin{array}{c}\text { Keteranga } \\
\text { n }\end{array}$ \\
& & & $\boldsymbol{d}$ & \\
\hline $\begin{array}{c}\text { Poste } \\
\text { s }\end{array}$ & $\begin{array}{c}2,50 \\
7\end{array}$ & 58 & 0,015 & $\begin{array}{c}0,007 \\
5\end{array}$ & Tolak Ho \\
\hline
\end{tabular}

Berdasarkan Tabel 4 dapat dilihat bahwa nilai signifikansi satu pihak pada nilai postes kemampuan pemahaman matematis lebih rendah dari nilai $\alpha=0,05$ yaitu 0,0075 maka $\mathrm{H}_{\mathrm{o}}$ ditolak. Hal tersebut dapat diartikan bahwa peningkatan kemampuan pemahaman matematis siswa yang belajar dengan software cabry II plus lebih baik daripada siswa yang belajar dengan pembelajaran biasa.

\section{Tabel 5. Hasil Uji Perbedaan Dua Rerata N-Gain Kemampuan Pemahaman} Matematis Siswa

\begin{tabular}{|c|c|c|c|c|c|}
\hline $\begin{array}{c}\text { Sko } \\
\text { r }\end{array}$ & $\begin{array}{c}\text { Man } \\
\text { n- } \\
\text { Whit } \\
\text { ney } \\
\text { U }\end{array}$ & $\mathbf{Z}$ & $\begin{array}{c}\text { Asymp. } \\
\text { Sig. (2- } \\
\text { tailed) }\end{array}$ & $\begin{array}{c}\text { Asymp. } \\
\text { Sig. (1- } \\
\text { tailed) }\end{array}$ & Ket \\
\hline $\begin{array}{c}\mathrm{N}- \\
\text { Gai } \\
\mathrm{n}\end{array}$ & $\begin{array}{c}377.0 \\
00\end{array}$ & $\begin{array}{c}- \\
1,0 \\
98\end{array}$ & 0,272 & 0,136 & $\begin{array}{c}\text { Teri } \\
\text { ma } \\
\mathrm{H}_{\mathrm{o}}\end{array}$ \\
\hline
\end{tabular}

Pada Tabel 5 dapat diketahui bahwa data nilai n-gain dilakukan dengan uji MannWhitney karena data pretes tidak berdistribusi normal. Kriteria pengujian dengan uji Mann-Whitney dengan $\alpha=0,05$ adalah jika sig (1-tailed) $\geq \alpha$ maka $\mathrm{H}_{\mathrm{o}}$ diterima. Namun, jika sig (1-tailed) $<\alpha$ maka $\mathrm{H}_{\mathrm{o}}$ ditolak. nilai signifikansi satu pihak pada nilai n-gain kemampuan pemahaman matematis lebih tinggi dari nilai $\alpha=0,05$ yaitu 0,136 maka $\mathrm{H}_{\mathrm{o}}$ diterima. Hal tersebut dapat diartikan bahwa peningkatan kemampuan pemahaman matematis siswa yang belajar dengan software cabry II plus tidak lebih baik daripada siswa yang belajar dengan pembelajaran biasa.

pernyataan, dimana terdapat 23 butir pernyataan positif dan 2 butir pernyataan negatif. Angket tersebut memiliki 5 pilihan jawaban untuk setiap butir pernyataan yaitu SL (Selalu), SR (Sering), KD (KadangKadang), JR (Jarang) dan TP (Tidak 
Pernah). Angket ini diberikan kepada siswa kelas eksperimen dengan tujuan untuk melihat motivasi siswa yang belajar matematika dengan software cabry II plus. Pengelompokan motivasi belajar siswa didasarkan atas range untuk setiap tingkatan motivasi belajar, yaitu siswa yang memiliki motivasi tinggi $(7,5 \leq \mathrm{x} \leq 100)$, siswa yang memiliki sedang $(50 \leq \mathrm{x} \leq 75)$ dan siswa yang memiliki motivasi rendah $(\mathrm{x}<50)$. Oleh karena itu, penulis dapat mengetahui jumlah siswa untuk setiap tingkatan motivasi belajar siswa berdasarkan skor angket.

Pada skor nilai, dapat diketahui bahwa siswa yang memiliki skor tertinggi dan terendah masing-masing adalah 113 dan 55 . Selisih dari skor nilai siswa yang memiliki motivasi tinggi dengan siswa yang memiliki motivasi rendah adalah 58. Persentase rerata terendah yang diperoleh siswa adalah 44, sedangkan persentase rerata skor tertingginya adalah 90,40. Selisih dari persentase rerata skor terendah dan skor tertinggi adalah 46,40. Siswa yang belajar dengan software cabry II plus secara keseluruhan memiliki motivasi sedang dengan skor rerata adalah 71,90. Jumlah siswa yang memiliki motivasi tinggi, sedang dan rendah di kelas eksperimen masing-masing adalah 14 siswa, 16 siswa dan 3 siswa. Jika dipandang berdasarkan persentase untuk motivasi tinggi, sedang dan rendah masing-masing adalah 48,48 \%, 42,42\% dan 9,09\%. yaitu Berdasarkan jumlah tersebut, sudah terlihat bahwa dominan siswa memiliki motivasi sedang di kelas eksperimen.

Hasil rerata nilai pretes kemampuan pemahaman matematis siswa di keles eksperimen adalah 3,83; sedangkan di kelas kontrol adalah 3,27. Selisih dari kedua rerata nilai pretes kelas adalah 0,56. Jika dilihat dari persentase rerata nilai pretes untuk kelas eksperimen adalah 42,56\%; sedangkan di kelas kontrol adalah 36,33\%. Selisih persentase rerata nilai pretes kemampuan pemahaman matematis dari kedua kelas adalah 6,23 \%. Selisih rerata nilai pretes kemampuan pemahaman matematis siswa tidak jauh berbeda. Nilai signifikan dari hasil uji kesamaan dua rerata pretes kemampuan pemahaman matematis adalah 0,223, dimana sig $>\alpha=0,05\left(H_{0}\right.$ diterima). Hal tersebut menunjukkan bahwa tidak terdapat perbedaan kemampuan awal (kemampuan pemahaman matematis) siswa kelas eksperimen dan kelas kontrol.

Hasil rerata nilai postes kemampuan pemahaman matematis siswa di keles eksperimen adalah 6,83; sedangkan di kelas kontrol adalah 5,77. Selisih dari kedua rerata nilai pretes kelas adalah 1,06. Jika dilihat dari persentase rerata nilai pretes untuk kelas eksperimen adalah 75,89 \%; sedangkan di kelas kontrol adalah 64,11\%. Selisih persentase rerata nilai pretes kemampuan pemahaman matematis dari kedua kelas adalah 11,78\%. Selisih rerata nilai pretes kemampuan pemahaman matematis siswa lebih tinggi dibanding selisih rerata nilai pretes kemampuan pemahaman matematis siswa yaitu sebesar $5,55 \%$. Walaupun begitu, nilai tertinggi dan terendah dari postes kemampuan pemahaman matematis awal siswa juga sama dari kedua kelas yaitu 9 dan 3. Nilai signifikan dari hasil uji perbedaan dua rerata postes kemampuan pemahaman matematis adalah 0,015, dimana sig $<\alpha=$ 0,05 ( $H_{0}$ ditolak). Hal ini menunjukkan bahwa peningkatan kemampuan pemahaman matematis siswa yang belajar dengan software cabry II plus lebih baik daripada siswa yang belajar dengan pembelajaran biasa. 


\section{SIMPULAN}

Peningkatan kemampuan pemahaman matematis siswa yang belajar dengan software cabry II plus tidak lebih baik daripada siswa yang belajar dengan pembelajaran biasa dan siswa yang belajar dengan software cabry II plus memiliki motivasi belajar sedang secara keseluruhan.

\section{DAFTAR PUSTAKA}

[1] E. T Ruseffendi. Dasar-Dasar Penelitian Pendidikan dan Bidang Non-Eksakta Lainnya. Bandung: Tarsito, 2005.
[2] R. Hikmah. "Penerapan Model Advance Organizer untuk Meningkatkan Kemampuan Pemahaman dan Analogi Matematis Siswa SMP". Jurnal Susunan Artikel Pendidikan (SAP), vol 1,no. 3, pp. 271-280, 2017.

[3] S. Maarif. "Membelajarkan Geometri dengan Cabri Geometry II Plus". Prosiding Seminar Nasional Pendidikan Matematika 2014 Matematika Program Studi Pendidikan Matematika Universitas Muhammadiyah Prof.DR.HAMKA, pp. 140-159, 2014. 